\title{
Analysis of Economic Development Based on Environment Resources in the Mining Sector*
}

\author{
Munawir NAZIR ${ }^{1}$, Imaduddin MURDIFIN ${ }^{2}$, Aditya Halim Perdana Kusuma PUTRA ${ }^{3}$, \\ Nasir HAMZAH ${ }^{4}$, Moch Zulkifli MURFAT ${ }^{5}$
}

Received: March 14, 2020 Revised: April 04, 2020 Accepted: May 07, 2020

\begin{abstract}
The purpose of this study is to investigate the economic potential of the regions from the mining sector of North Morowali, CentralSulawesi, Indonesia, and the formulation of pro-business regional development management that aims to create synergy between the local government and mining sector entrepreneurs. This study uses a descriptive qualitative approach by taking data in the form of primary data from FGD and secondary data observations from statistical bureau data in the North Morowali, Indonesia. The analysis unit uses SWOT analysis to determine the economic potential of the North Morowali and Location Quotient (LQ) to analyze the economic potential of the mining sector. The research period covers one year (2018-2019) in North Morowali, Indonesia. All the mining products have considerable potential as a financing unit in North Morowali, while mining potential has not been maximally exploited. The absence of regulations, facilities such as road access, and optimal land and sea transportation are the causes of the difficulty of optimization and access to explore mining products comprehensively. As a new province at Central Sulawesi, more efforts and the role of government are needed to focus attention to North Morowali as an area with great potential in the mining sector.
\end{abstract}

Keywords : Economics Potential, Minning Sectors, Economics Development, Location Quotient

JEL Classification Code: H1, H5, J1

\section{Introduction}

*Thanks to North-Morowali Government, North-Morowali BAPELITBANGDA (Local Goverment Research and Development), LP2S-UMI (Research and Human Resource Development Institute of Universitas Muslim Indonesia), Besides, thanks to North Morowali Community, Mining Stakeholders, reviewer and editors.

${ }^{1}$ First Author. Assistant Professor, Faculty of Economics and Business, Universitas Muslim Indonesia, Makassar, Indonesia

${ }^{2}$ Associate Professor, Faculty of Economics and Business, Universitas Muslim Indonesia, Makassar, Indonesia

${ }^{3}$ Corresponding Author. Assistant Professor, Faculty of Economics and Business, Universitas Muslim Indonesia, Makassar, Indonesia [Postal Address: Jalan Tamalate 1 Tidung 4 Number 143, Makassar City, South Sulawesi, 90222, Indonesia] Email: adityatrojhan@gmail.com

${ }^{4}$ Full Professor, Faculty of Economics and Business, Universitas Muslim Indonesia, Makassar, Indonesia

${ }^{5}$ Assistant Professor, Faculty of Economics and Business, Universitas Muslim Indonesia, Makassar, Indonesia

(c) Copyright: The Author(s)

This is an Open Access article distributed under the terms of the Creative Commons Attribution Non-Commercial License (http://Creativecommons.org/licenses/by-nc/4.0/) which permits unrestricted noncommercial use, distribution, and reproduction in any medium, provided the original work is properly cited.
Local governments and entrepreneurs are the two most influential groups in determining the pattern of regional economic growth (Arfah \& Putra, 2019; Leydesdorff, Ivanova, \& Meyer, 2019). Local governments have advantages in one thing, namely, the ability to execute the development potential of the region, though it has, of course, limitations in other areas. The synergy between the government and entrepreneurs' aims in planning is critical, so that the regional economy can be productive, efficient, and sustainable (Murdifin et al., 2018; Di Zhang \& Swanson, 2013; Chamidah, Guntoro, \& Sulastri, 2020). Local governments have the opportunity to implement various regulations, provide multiple means, and form community insights related to economic factors in the context of improving people's welfare (Mewes \& Mau, 2013). But local governments do not know much about how the process of economic activity takes place, while entrepreneurs can recognize the needs of many people, and with various initiatives to meet those needs (Yusuf \& Putra, 2019) \& (Mewes \& Mau, 2013). Activities that meet these needs aim to make the wheels of the economy turn, generate 
salaries and wages for workers, and taxes for the government (Putra et al., 2019; Mashur et al., 2019; Vis, 2009; Akob, Arianty, \& Putra, 2020; Haerani et al., 2020). With revenues, local governments have the opportunity to create conditions so that the regional economy develops further.

Regional governments, in maintaining the sustainability of their local economic development, have a beneficial impact on residents' need to understand that regional development management can have a good influence on achieving the expected economic development goals (Merdika et al., 2019; Putra et al., 2019; Tulsi \& Ji, 2020). If the development management policy is not on target, it will cause a slowdown in the economic growth. Therefore, regional development management has the potential to increase economic development and create profitable business opportunities and, thus, accelerate the pace of regional economic growth (Ongsakul \& Sen, 2019; Indahingwati et al., 2019).

The principles of pro-business development management are to provide information to entrepreneurs in their area or outside their area when, where, and about what types of investments are following the future development needs (Homayoun, Al-Thani, \& Homayoun, 2016). In this way, the entrepreneur can know the direction of the regional development policy desired by the local government, so that it can be used as a basis for consideration in determining what activities the business will need to develop. Local governments need to be open about their development policies, and information received by the public needs to be pursued by what is desired (Appiah et al., 2018). Besides, it provides policy certainty and clarity. Because one of the obstacles to business is the changing pattern and direction of public policy (Susanto, 2019), while investors need certainty about the course and objectives of government policy. An excellent regional economic development strategy can make entrepreneurs believe that their investment will generate profits in the future because it is the primary concern of prospective investors; it is a matter of policy certainty that is a fundamental problem (Putra et al., 2018). Local governments must avoid overlapping policies, so that the role of entrepreneurs in developing regional economies becomes flexible (Meiyani \& Putra, 2019; Choi, Kim \& Kim, 2019). This requires mutual communication between the determinants of regional economic development. In this way, an agency can know what is being done. It will be done by other agencies to reduce the occurrence of similar activities or the lack of support for funding activities that are not needed.

Then, what the government is obliged to take is to encourage the service and trade sector (Hodge, 1998). Because the economic sector, which is generally developing fast in cities, is the small trade and services sector. This sector is very dependent on the distance and level of population density (Miroudot, Sauvage, \& Shepherd,
2012). Distant population distribution and low population density will weaken the service sector and retail trade, resulting in reduced employment opportunities. The closer the population, the interaction between them will encourage service sector activities and trade. Small traders should have a secure place to try because it has helped local governments reduce unemployment. Increasing competitiveness is to increase competition itself. This means that unique treatments must be abandoned. Protection needs to be removed immediately or gradually (Kousky, Luttmer, \& Zeckhauser, 2006). Successful product development is market-oriented; this means local governments need to encourage entrepreneurs to always improve technical and economic efficiency. International trade regulations must be introduced and applied. There needs to be a planned effort, so that each regional government official understands these international trade regulations to be able to encourage regional entrepreneurs to become strong players in free trade, both at the regional, national, and international level (Ulph, 1994; McCright, Xiao, \& Dunlap, 2014).

The purpose of government involvement is to form a framework that encourages economic activity. In other words, creating a private space for economic activity will more directly drive this economic activity. Local governments need to try to anticipate which areas can be grown into centers of the regional economy (Putra \& Nasir, 2018). These strategic and fast-growing areas can be in the form of cities that have shown signs of agglomeration, such as centers of agricultural production of food crops, horticulture, plantations, livestock, fisheries, industrial cluster, etc. Fast-growing areas can also be areas that have been deliberately developed to exploit the potential of untreated natural resources, such as those previously established with the transmigration settlement system. These areas need to be recognized and subsequently grown with various efforts to develop economic activities, such as the procurement of an agribusiness terminal, road hardening, business training, promotion, etc. The development of these strategic and fast-growing areas needs to be done together with efforts to increase skills, business development, and strengthen community empowerment.

\section{Literature Review}

\subsection{Mining Activities in Indonesia}

The role of the mining and energy sectors in Indonesia's development is significant. The mining and energy sectors are the leading foreign exchange earners, providing the most substantial energy resources and absorbing labor. As foreign exchange-earners, these sectors' contribution to Indonesian Five-Years Development Plan Policy (REPELITA) II has increased. If at the beginning of Repelita II, $55 \%$ of foreign exchange earnings came from the mining and energy sectors, 
then at the end of Repelita II, the contribution had increased to more than $70 \%$. Even more encouraging is that the types of mining products produced and exported are now more diverse, thanks to the success of diversification efforts during Repelita II (Hidjaz, 2019).

Besides, most of the energy resources used in the Indonesian economy come from mining, namely, oil and coal. Mining development, which is an embodiment of the mandate of the 1945 Constitution Article 33, in essence, constitutes an effort to develop mineral and energy resources that can potentially to be used efficiently and optimally for the interests and prosperity of the people, through a series of exploration and exploitation activities, and utilization of mining products. These efforts are based on the utilization of various resources, mainly mineral and energy natural resources, supported by quality human resources, mastery of science and technology, and management capabilities. Mining development is an integral part of national development to realize the ideals of the nation to achieve a just and prosperous society that is evenly materially and spiritually based on Pancasila and the 1945 Constitution (Syahuri, 2016).

Natural mineral and energy resources have distinctive characteristics that require approaches according to their development. The unique features of the mining sector that need to be considered in mining development, among others, are the natural resources of the mine occupying a particular spatial distribution in the earth and the seabed; these are available in limited quantities and are generally non-renewable; its operations involve investment and riskladen activities, which often must be capital and technologyintensive; the mining process has a high potential for environmental change; mineral and energy mining products have a dual function, mainly as a source of industrial raw materials and energy, both for domestic and export needs; and the mining business is able to play a role as the prime mover and spearhead of regional development, in addition to its role in fulfilling the livelihoods of the wider community (Hidjaz, 2019; Nguyen et al., 2020; Nguyen, 2020).

The Indonesian Guidelines of State Policy (GBHN) 1993 mandate that in the Long-Term Development II the utilization of natural resources as the main points of people's prosperity is carried out in a planned, rational, optimal, responsible fashion and in accordance with the capacity of the people to prioritize their greatest success and pay attention to the preservation of environmental functions and balance for sustainable development (Islam et al., 2017). National spatial planning with an insight into the archipelago is used as a guide for the event plan, so that ecological management and the utilization of natural resources can be carried out safely, orderly, efficiently, and effectively. Furthermore, the GBHN in 1993 also outlined that economic development that manages Indonesia's earth wealth, such as mining, must always pay attention that natural resource management must also guarantee future life. Renewable natural resources must be handled in such a way that their functions can be maintained throughout the ages. Therefore, natural resources must be maintained, so that their ability to renew is always maintained. Non-renewable natural resources must be used as economically and judiciously as long as possible. Thus, the main task of the mining sector is to carry out natural resource management in an efficient and optimal manner, as well as implementing an environmentally-sound mining system.

North Morowali as a district of Central Sulawesi Province, Indonesia that was formed recently in 2012, the development of the regional economy when viewed from the Central Statistics bureau data in 2016, regional generated revenue (PAD) of North Morowali Regency showed a significant increase despite the decline in 2015. Two years after it was formed, namely, in 2014 (in nominal million Indonesian rupiahs), it showed that the Local Generated Revenue (PAD) was in the amount of IDR40,673,134,304, which increased from the previous year to 2013, amounting to IDR39,134,372,089, whereas the biggest revenue of North Morowali Regency is principally derived from the contribution of the agriculture and mining sectors. Several mining companies are currently operating in North Morowali Regency, but not sufficiently to shape a more optimal regional economy (BPS, 2018). To achieve the objectives and targets in improving the regional economy, a local economic development plan in the regency of Morowali Utara needs to be directed, measured and competently executed in accordance with the conditions, problems, potentials and needs of the region, especially for the mining sector as a base sector that contributes to regional income. The stages of preparing an economic development strategy in North Morowali Regency can be done including:

[1]. Identify the mining sector and types of mining minerals that have the economic potential to be developed by taking into account the strengths and weaknesses of each segment through SWOT analysis.

[2]. Identify existing resources (factors of production), including human resources that are ready to be used to support the development of each sector concerned.

[3]. Determine the strategy to be adopted for the development of the mainstay mining sector that will be able to attract other industries to grow, so that the economy will be able to develop by itself sustainably.

Based on the purpose of introducing regional potential, the two fundamental principles of local economic 
development can be achieved through the introduction of regional economic potential and the formulation of probusiness regional development management.

\section{Research Methods and Measurement}

The quantitative approach in this study was carried out through the use of secondary data available in each district/ city. Central Bureau of Statistics publications in the form of districts/cities in numbers for several years of release will be the primary source of secondary data, in addition to the data sources available in each regional or local government agency (SKPD). Simple descriptive analysis and projection models are used in a quantitative approach. While the qualitative approach was carried out to obtain primary data using literature studies, observations, in-depth interviews with local stakeholders, and focus group discussions (FGD) in the regions. The purpose of the in-depth interview is to get an overview of the economic and social conditions and their aspirations regarding regional economic development going forward. The results of the meeting are summarized in an initial finding, which is then presented in the FGD forum to obtain weaknesses, strengths, and consensus on aspects related to future economic development planning.

Empirical data analysis is divided into three, namely, (i) descriptive data analysis, (ii) proportion analysis, and (iii) time series analysis (projection). Descriptive data analysis provides analysis of available secondary data, such as growth trends, maximum values, minimum values, and cross-tabulation if necessary. While the proportion analysis aims to see the strength of the regional economy. The calculated indicator is a sectoral contribution to the Gross Domestic Regional Product. While the time series analysis is carried out to project essential variables that are indicators of economic growth, such as Gross Domestic Regional Products. The technique used is a regression model using secondary data that is time series. In detail, some logical concepts and mathematical calculations from some of the analysis techniques above are described in the LQ analysis. Location Quotient is a method of study that is commonly used in the field of geography economics (Miller, Gibson, \& Wright, 1991).

However, LQ is often also used in other areas of science. Blakely, Bista, \& Lubulwa, (2008) states that LQ is an analytical technique used to complement other analyzes, namely, shiftshare analysis. Regarding intra and inter-regency goods and services flow, an analysis of identification of leading sectors that have the potential to be developed in North Morowali Regency will be analyzed. It will be seen from the possibility, income creation and interactions with other divisions within and outside the region, so that one can identify the economic industry, which is able to meet the needs of the community in the area of North Morowali Regency itself and the potential to move outside the city. For this reason, knowing the real specifications of the sector or economic activity in a planning area, the Location Quotient Method (LQ) can be used with the period 2015 - 2018 (BPS, 2018).

$$
\mathrm{LQ}=\frac{P V-S R(\text { Year }) / G D P R}{P P V-S R / G D P R}
$$

Infomation:

LQ = Location Quotient

PV-SR $=$ Production value of sub-sector regency

GDPR $=$ Total Province GDP Regional

\section{Description:}

[1]. if $L Q>1$ means that the sub-sector is the leading sub-sector in the region and has the potential to be developed as a driver of the regional economy.

[2]. If $\mathrm{LQ}<1$ means that the sector is not a leading subsector in the region and has less potential to be developed as a driver of the regional economy.

Furthermore, after passing through the LQ analysis process, the next step is to classify the potential from the internal and external angles in the form of strengths, weaknesses, opportunities, and threats that will be obtained by using a SWOT analysis. The results of the SWOT analysis will be compared from the results of the FGD interviews, where the results of this analysis will obtain an alternative strategy for the formulation of the economic development of North Morowali Regency, Indonesia, through the mining sector.

\section{Results and Discussion}

\subsection{Demography}

Appendix 1 explains the predicted population growth used to find out how the population growth rate in an area. This population growth rate can be obtained by identifying the population in each year of a time series, the price of population growth in ten districts in North Morowali in 2018-2027. An analysis of population characteristics by age is carried out at intervals for 2018, as in Table 1. Whereas Appendix 2 presents the population over the age of 15 and above by labor or non-labor force and by the highest level of education completed, as well as detailing the number of job seekers registered according to the highest level of education ended and their gender.

\subsection{Location Quotient (LQ) Analysis}

Some production results for the sector in North Morowali Regency show that there are sectors that are both base and non-base and can be developed further to encourage the 
increased contribution to Gross Domestic Regional Products. Appendix 3 describes the LQ allocation in the mining sector of Morowali Utara Regency 2015-2018 by comparing the value of Gross Domestic Product (GDP) based on constant prices (ADHK), and Gross Domestic Regional Product (PDRB). Subcategory of oil and gas mining and geothermal includes the activities of crude oil production, drilling, and extraction of oil from oil shale and oil sands and natural gas production as well as the search for hydrocarbon liquids. This subcategory also includes operations and development of oil, natural gas, and geothermal mining sites.

Coal mining covers the business of mining operations, drilling of various qualities of coal such as anthracite, bituminous and sub-bituminous both underground and underground mining, including mining by liquefaction. The mining operation includes excavation, crushing, washing, filtering, and mixing as well as compaction to improve quality or facilitate transportation and storage. Including the search for coal. Lignite mining includes surface mining, liquefaction mining and other activities to improve quality and facilitate transportation and storage. The metal ore subcategory includes extraction and processing of metal ore that does not contain iron, such as thorium ore and uranium, aluminium, copper, tin, zinc, lead, manganese, chromium, cobalt nickel, and others. It includes other precious metal ores. Other expensive metal ore groups include cleaning and refining, which cannot be administratively separated from other metal ore mining businesses.

Table 1: Analysis of Population Characteristics by AgeGroup and Gender

\begin{tabular}{|c|c|c|c|}
\hline Age Group (Years) & Men & Women & Total \\
\hline $0-4$ & 6.726 & 6.346 & 13.072 \\
\hline $5-9$ & 6.053 & 5.757 & 11.810 \\
\hline $10-14$ & 5.319 & 4.965 & 10.284 \\
\hline $15-19$ & 5.017 & 4.244 & 9.261 \\
\hline $20-24$ & 5.411 & 4.980 & 10.391 \\
\hline $25-29$ & 5.415 & 4.697 & 10.112 \\
\hline $30-34$ & 5.252 & 4.799 & 10.051 \\
\hline $35-39$ & 4.917 & 4.395 & 9.312 \\
\hline $40-44$ & 4.840 & 4.320 & 9.160 \\
\hline $45-49$ & 4.201 & 3.774 & 7.975 \\
\hline $50-54$ & 3.280 & 2.909 & 6.189 \\
\hline $60-64$ & 2.503 & 2.385 & 4.888 \\
\hline $65-69$ & 1.977 & 1.725 & 3.702 \\
\hline $70-74$ & 920 & 998 & 2.596 \\
\hline 75 up & 1.052 & 1.212 & 2.264 \\
\hline Total & $\mathbf{6 4 . 1 8 1}$ & $\mathbf{5 8 . 8 0 4}$ & $\mathbf{1 2 2 . 9 8 5}$ \\
\hline
\end{tabular}

Some types of products include iron sand and iron ore mining and improvement of the quality and agglomeration of iron ore, mining and processing of non-ferrous metal ore, such as thorium and uranium ore, aluminium (bauxite), copper, tin, zinc, tin black, manganese, chrome, cobalt nickel and others; and mining of precious metal ores, such as gold, platinum, silver and other precious metals. The mining and quarrying subsector includes the excavation and extraction of all types of excavated items such as rocks, sand, and soil, which are generally located on the surface of the earth. The results of this activity are mountain rocks, river stones, limestone, coral, gravel, coral, marble, sand for building materials, silica sand, quartz sand, kaolin, clay, and excavation commodities other than those mentioned above. Included in this subcategory are excavated salt commodities.

The manufacturing industry category includes economic activities in the field of chemical or physical change from materials, elements, or components into new products. Raw materials for processing industries come from agricultural, forestry, fishery, mining, or quarrying products such as products from other processing industry activities. Changes, updates, or reconstruction of the principal goods are generally treated as processing industry. The processing industry unit is described as a factory, machine or equipment that is primarily driven by machine and hand. Included in the processing industry category are the conversion of materials into new products by hand, macro activity, or product sale activities made in the same place where the product is sold and the unit that processes the materials from the other party on a contractual basis. These subcategories include the activities of transforming oil, gas, and coal into useful products such as oil and gas mills, which include the separation of petroleum into component products through techniques such as breakdowns and refineries. Included in the processing industry category are the conversion of materials into new products by hand, macro activity, or product sale activities made in the same place where the product is sold and the unit that processes the materials from the other party on a contractual basis. These subcategories include the activities of transforming oil, gas, and coal into useful products such as oil and gas mills, which include the separation of petroleum into component products through techniques such as breakdowns and refineries.

Table 2 shows that the petroleum and geothermal subsector has decreased from 2017 to 2018, but this subsector base can be further developed. The coal and lignite subsector is a subsector that is close to the support and has the potential to be developed while other excavations subsector, although it has a contribution to the Gross Domestic Regional Product of North Morowali regency but is not a base and is very difficult to develop its potential. 


\subsection{Analysis of Development Policy for the Mining and Quarrying Sector}

Mineral and metal ore mining tend to be highlighted as a source of state revenue through tax and non-tax state revenue from the Energy and Mineral Resources Sub Sector. This cannot be denied considering that, from year to year, the contribution of state revenue from minerals and coal continues to increase significantly in the total state revenue of the Energy and Mineral Resources Sector in the National Budget (APBN). The role of the mining sector, especially for North Morowali Regency, plays an essential role in terms of state revenue and increasing the value of an investment for the nation. One of the mandates of Law Number 4 of 2009 concerning Mineral and Coal Mining (Mineral and Coal Law) is to increase the value-added of minerals and coal. Based on Articles 103 and 170 of the Mineral and Coal Law, minerals must be added to the value-added through processing and refining minerals in the country.

Provisions on the obligation to increase mineral valueadded through mineral processing and refining in the country, especially for holders of an Additional Business License (IUP) and a Special Mining Business License (IUPK) for Production Operations, are implemented in the Minister of Energy and Mineral Resources Regulation Number 7 of 2012 concerning Increase in Mineral Value Added through Mineral Processing and Refining Activities in the Country. Prior to the enactment of the Minister of Energy and Mineral Resources Regulation Number 7 of 2012 amended by Minister of Energy and Mineral Resources Regulation Number 1 of 2014, there was a massive increase in exports during the period 2008-2011 due to the lack of export trading arrangements for mineral commodities in the form of ore (raw material) for several mining commodities such as nickel ore (increasing 8-fold), iron ore and iron sand (increased 7-fold), copper ore (11-fold increase), and bauxite ore (5-fold growth). The obligation to increase this added value, encourage the construction of mineral processing and refining plants in the country (smelters) so that minerals produced by mineral mining companies can be processed and refined domestically.

Several strategic steps need to be fostered by the North Morowali Regency government pertaining to regulations and policies for the mining and quarrying sector. For example, such as renegotiating mining contracts and structuring mining business licenses. Renegotiation of mining contracts must have a positive impact on the North Morowali Regency, such as increasing the value of Gross Domestic Regional Products. Included in this is an increase in the amount of social responsibility as a form of moral responsibility of mining companies to the community in the North Morowali Regency. Absorption of local labor, provision of access to public facilities, and facilities is something that can be demanded by the North Morowali Regency government to mining companies to synergize with North Morowali Regency. This can be achieved through the creation of a conducive investment climate which is carried out through the stages of mining conservation and supervision.

\subsection{SWOT Analysis of Human Resurces Development as a Strategy for Developing Economic Potential}

Mining in North Morowali is a sector that contributes significantly to the North Morowali Regency Gross Domestic Regional Product which is explained in the SWOT analysis as in Appendix 4. To improve the investment climate in North Morowali Regency, it is necessary to improve the quality of human resources that can support existing developments. The potential of human resources that can be used as capital in the supply of labor for the development of the current economic sector needs to be supported by improving the quality of human resources. The strategic issues of human resource development in North Morowali Regency are:

[1]. The low quality and productivity of the workforce are caused by low levels of education and workforce skills.

Table 2: Mining and Quarry Productions (in million rupiahs)

\begin{tabular}{|c|c|c|c|c|c|}
\hline Commodity & 2017 & 2018 & $\Sigma L Q$ & LQ Part & Info \\
\hline Oil, Gas, and Geo-thermal & 611.861 & 201.241 & \multirow{5}{*}{1,7} & 0.12 & $\begin{array}{l}\text { Base decreases } \\
\text { can be developed }\end{array}$ \\
\hline Coal and lignite & 0 & 0 & & 0 & - \\
\hline Metal ore & 758.496 & 1.399 .799 & & 0.84 & $\begin{array}{l}\text { Bases can be } \\
\text { developed }\end{array}$ \\
\hline Other excavations & 50.977 & 97.574 & & 0.05 & Not a base \\
\hline Total & 1.421 .334 & 1.658 .274 & & & \\
\hline
\end{tabular}


[2]. The lack of employment opportunities caused by an imbalance between existing employment opportunities and the community's need for employment and absorption of the existing workforce are not proportional to the growth of the workforce so that the number of unemployed increases.

From the findings of the analysis and strategic issues developing Human Resources development, it can be formulated that each influential factor in the study of HRM development strategies is as described in Appendix 5, which, from the results of the SWOT analysis that has been done, it can be concluded that the human resource development strategy in North Morowali are: increasing access to information and technology to improve human resources; improving community organization institutions; enhancing community skills in natural resource management through skills training; and developing media socialization (Lee \& Syah, 2018).

\section{Conclusions}

To build a sustainable economic development program, a program planning mechanism that is organized according to the Regional Spatial Plan is needed without ignoring the impact on the environment; it should also optimize the human resources and resources that are around the development area. From the analysis of the determination of potential development strategies to support economic improvement in the North, Morowali Regency will be used as a basis in the process of economic development strategies that will be carried out. The policy coming out of the results of this analysis will later be revealed in a planned development program and based on a study of the development of existing economic and investment potential.

Investment policy orientation must be directed towards potential sectors in North Morowali Regency. To further enhance economic competitiveness in North Morowali District, improvement is needed in various fields such as infrastructure and quality of human resources, and optimizing natural resources that are utilized as capital in investment and economic development. This way, North Morowali Regency will remain a destination for stakeholders/actors efforts to invest and have more competitiveness in the domestic and foreign markets. From the results of this analysis, it can be concluded that there is a need to improve investment competitiveness that requires investment development strategies. The investment development/investment strategy in North Morowali Regency, in general, should be as follows:

[1]. Development of the potential of the regency's economic sector through the development of superior commodities, mainstays, and potentials that become product competitive through strengthening upstream- downstream.

[2]. Development of regional infrastructure to attract investors to support increased investment in the North Morowali Regency.

[3]. Strategies for strengthening human resources in an effort to improve the quality of knowledge and skills of the workforce.

[4]. Development of a regional investment potential information system that contains the potentials of various leading economic sectors, procedures for investment procedures, district spatial pattern policies, and incentive and disincentive arrangements.

[5]. Development of networking through various promotional business activities, and utilization of information technology to support investment competitiveness in the North Morowali Regency.

[6]. Increased support for developing capital networks through collaboration with various parties, both private and banking financial institutions

[7]. Renewal of contracts for mining companies that promote regional development as part of the strength of North Morowali Regency.

\section{References}

Akob, M., Arianty, R., \& Putra, A. H. P. K. (2020). The Mediating Role of Distribution Kahn's Engagement: An Empirical Evidence of Salesforce in Indonesia. The Journal of Asian Finance, Economics and Business, 7(2), 249-260. https://doi. org/10.13106/jafeb.2020.vol7.no2.249

Appiah, M. K., Possumah, B. T., Ahmat, N., \& Sanusi, N. A. (2018). Policy Environment and Small and Medium Enterprises Investment in the Ghanaian Oil and Gas Industry. International Journal of Energy Economics and Policy, 8(4), 244-253.

Arfah, A., \& Putra, A. H. P. K. (2019). Analysis of Productivity and Distribution of Female Workers in FB's Industries. Journal of Distribution Science, 17(3), 31-39. https://doi.org/10.15722/ jds.17.3.201903.31

Blakely, E. J., Bista, S., \& Lubulwa, G. (2008). Crafting economic drivers for local areas in globalising regional economy: Sydney as a case study. Sydney, Australia: Sydney University Press. ISBN 9781920899127, 1-233.

BPS. (2018). North Morowali Regency in Figures. Retrieved March 01, from https://morowaliutarakab.bps.go.id/ or https:// bit.ly/39jS44u

Chamidah, N., Guntoro, B., \& Sulastri, E. (2020). Marketing Communication and Synergy of Pentahelix Strategy on Satisfaction and Sustainable Tourism. Journal of Asian Finance, Economics and Business, 7(3), 177-190. https://doi. org/10.13106/jafeb.2020.vol7.no3.177 
Choi, C., Kim, C., \& Kim, C. (2019). Towards Sustainable Environmental Policy and Management in the Fourth Industrial Revolution: Evidence from Big Data Analytics. Journal of Asian Finance, Economics and Business, 6(3), 185-192. https://doi.org/10.13106/jafeb.2019.vol6.no3.185

Di Zhang, D., \& Swanson, L. A. (2013). Social entrepreneurship in nonprofit organizations: An empirical investigation of the synergy between social and business objectives. Journal of Nonprofit \& Public Sector Marketing, 25(1), 105-125. https:// doi.org/10.1080/10495142.2013.759822

Halim Perdana Kusuma, A., Kadir, A., Muis, M., Nurhilalia, \& Jusni. (2019). Determinant of Market Orientation on SME Performance: RBV and SCP Perspective. Journal of Distribution Science, 17(9), 34-45. https://doi.org/10.15722/ jds.17.09.201909.35

Haerani, S., Sumardi, Hakim, W., Hartini, \& Putra, A. H. P. K. (2020). Structural Model of Developing Human Resources Performance: Empirical Study of Indonesia States Owned Enterprises. Journal of Asian Finance, Economics and Business, 7(3), 211-221. https://doi.org/10.13106/jafeb.2020. vol7.no3.211

Hidjaz, K. (2019). Effectiveness of Environmental Policy Enforcement and The Impact by Industrial Mining, Energy, Mineral, And Gas Activities In Indonesia. International Journal of Energy Economics and Policy, 9(6), 79-85. https:// doi.org/10.32479/ijeep.8146

Hodge, J. (1998). Developing a trade and industry policy agenda for service sectors in South Africa. TIPS Annual Forum. 1-41, Retrieved March 01, from http:/www.tips.org.za/files/179.pdf

Homayoun, S., Al-Thani, F. F. J., \& Homayoun, S. (2016). A Sustainability Accounting: Case Study on Exploration, Production and Midstream Activities at Maersk Oil. International Journal of Energy Economics and Policy, 6(1), 20-27.

Indahingwati, A., Launtu, A., Tamsah, H., Firman, A., Putra, A. H. P. K., \& Aswari, A. (2019). How Digital Technology Driven Millennial Consumer Behaviour in Indonesia. Journal of Distribution Science, 17(8), 25-34. http://dx.doi.org/10.15722/ jds.17.08.201908.25

Islam, M. Z., Ahmed, Z., Saifullah, M. K., Huda, S. N., \& AlIslam, S. M. (2017). CO2 Emission, Energy Consumption and Economic Development: A Case of Bangladesh. Journal of Asian Finance, Economics and Business, 4(4), 61-66. http:// dx.doi.org/10.13106/jafeb.2017.vol4.no4.61

Kousky, C., Luttmer, E. F. P., \& Zeckhauser, R. J. (2006). Private investment and government protection. Journal of Risk and Uncertainty, 33(1-2), 73-100. https://doi.org/10.1007/s11166006-0172-y

Lee, J. W., \& Syah, A. M. (2018). Economic and Environmental Impacts of Mass Tourism on Regional Tourism Destinations in Indonesia. Journal of Asian Finance, Economics and Business, 5(3), 31-41. http://doi.org/10.13106/jafeb.2018.vol5.no3.31

Leydesdorff, L., Ivanova, I., \& Meyer, M. (2019). Synergy in Innovation Systems Measured as Redundancy in Triple Helix
Relations. In Springer handbook of science and technology indicators. Springer. 421-443

Mashur, R., Gunawan, B. I., Ashoer, M., Hidayat, M., Perdana, H., \& Putra, K. (2019). Moving From Traditional to Society 5 . 0 : Case study by Online Transportation Business. Journal Distribution Science, 9, 93-102. http://dx.doi.org/10.15722/ jds.17.09.201909.93

McCright, A. M., Xiao, C., \& Dunlap, R. E. (2014). Political polarization on support for government spending on environmental protection in the USA, 1974-2012. Social Science Research, 48, 251-260. http://dx.doi.org/10.1016/j. ssresearch.2014.06.008

Meiyani, E., \& Putra, A. H. P. K. (2019). The relationship between islamic leadership on employee engagement distribution in FMCG industry: Anthropology business review. Journal of Distribution Science, 17(5), 19-28. http://dx.doi.org/10.15722/ jds.17.05.201905.19

Merdika, D., Sule, T., Kartini, D., Oesman, M., Halim Perdana Kusuma, A., Putra, K., \& Chamidah, N. (2019). Moderating of the Role of Technology Theory to the Existence of Consumer Behavior on e-commerce. 17, 15-25. https://doi.org/10.15722/ jds.17.07.201907.15

Mewes, J., \& Mau, S. (2013). Globalization, socio-economic status and welfare chauvinism: European perspectives on attitudes toward the exclusion of immigrants. International Journal of Comparative Sociology, 54(3), 228-245. https://doi. org/10.1177/0020715213494395

Miller, M. M., Gibson, L. J., \& Wright, N. G. (1991). Location quotient: A basic tool for economic development analysis. Economic Development Review, 9(2), 65-68

Miroudot, S., Sauvage, J., \& Shepherd, B. (2012). Trade costs and productivity in services sectors. Economics Letters, 114(1), 36-38. https://doi.org/10.1016/j.econlet.2011.09.005

Murdifin, I., Pelu, M. F. A. R., Putra, A. A. H. P. K., Arumbarkah, A. M., Muslim, M., \& Rahmah, A. (2018). Environmental Disclosure as Corporate Social Responsibility: Evidence from the Biggest Nickel Mining in Indonesia. International Journal of Energy Economics and Policy, 9(1), 115-122. https://doi. org/10.32479/ijeep.7048

Nguyen, T. L. H., Nguyen, T. T. H., Nguyen, T. T. H., Le, T. H. A., \& Nguyen, V. C. (2020). The Determinants of Environmental Information Disclosure in Vietnam Listed Companies. Journal of Asian Finance, Economics and Business, 7(2), 21-31. https:// doi.org/10.13106/jafeb.2020.vol7.no2.21

Nguyen, V. T. (2020). The Role of Foreign Direct Investment and Trade on Environmental Quality in Vietnam. Journal of Asian Finance, Economics and Business, 7(3), 289-294. https://doi. org/10.13106/jafeb.2020.vol7.no3.289

Ongsakul, V., \& Sen, S. K. (2019). Low Carbon Energy Symbiosis for Sustainability: Review of Shared Value-based Policy Metabolism to Enhance the Implementability of the Sustainable Development Goals in Asia. International Journal of Energy Economics and Policy, 9(2), 24-30. https://doi.org/10.32479/ijeep.7236 
Putra, A. H., Aswari, A., Arifin, M. Y., \& Rina, R. (2018). Quantitative Series: Factors Analysis Effects of Government Regulation Number 46 the Year 2013 For SME's by Justice, Convenience, and Simplicity of Tax Aspects. Substantive Justice International Journal of Law, 1(2), 65-81.

Putra, A. H. P. K., Ashoer, M., Abdullah, A., Muhtasom, A., Farida, I., \& Guntur, A. (2019). The Determinant of SME's Performance: The Main Role of Leadership Strategy, Knowledge, and Business Orientation. 1st International Conference on Life, Innovation, Change and Knowledge (ICLICK 2018). Atlantis Press. 430-434 https://doi.org/10.2991/iclick-18.2019.91

Putra, A. H. P. K., Nasir, M., \& Buana, A. P. (2018). Uncovering the Success of Tax Amnesty: Case Study on North Makassar Primary Tax Office. Jurnal Akuntansi Dan Pajak, 19(1), 60-68. http://dx.doi.org/10.29040/jap.v19i1.207

Susanto, A. B. (2019). The Effect Of Government Policy And Environmental Sustainability On The Performance Of Tourism Business Competitiveness: Empirical Assessment On The Reports Of International Tourism Agencies. International Journal of Energy Economics and Policy, 9(6), 439-446. https://doi.org/10.32479/ijeep.8297

Syahuri, T. (2016). Politics of Economic Law Based on Article 33 of the 1945 Constitution. Jurnal Konstitusi, 9(2), 243-258. https://doi.org/10.31078/jk\%25x
Tulsi, P., \& Ji, Y. (2020). A Conceptual Approach to Green Human Resource Management and Corporate Environmental Responsibility in the Hospitality Industry. Journal of Asian Finance, Economics and Business, 7(1), 195-203. https://doi. org/10.13106/jafeb.2020.vol7.no1.195

Ulph A. (1994) Environmental Policy, Plant Location and Government Protection. In: Carraro C. (eds) Trade, Innovation, Environment. Fondazione Eni Enrico Mattei (FEEM) Series on Economics, Energy and Environment, vol 2. Springer, Dordrecht, 123-163. https://doi.org/10.1007/978-94-0110948-2_6

Vis, B. (2009). The importance of socio-economic and political losses and gains in welfare state reform. Journal of European Social Policy, 19(5), 395-407. https://doi. org/10.1177/0958928709344250

Yusuf, M., \& Putra, A. H. P. K. (2019). The Impact of Product Quality, Price, and Distribution on Satisfaction and Loyalty. Journal of Distribution Science, 17(10), 17-26. http://dx.doi. org/10.15722/jds.17.10.201910.17 
Appendix 1: Predicted Population Growth Rate of Morowali Regency 2018 - 2027

\begin{tabular}{|l|c|c|c|c|c|c|c|c|c|c|}
\hline \multirow{2}{*}{ District } & \multicolumn{10}{|c|}{ Total Population (Person) } \\
\cline { 2 - 12 } & $\mathbf{2 0 1 8}$ & $\mathbf{2 0 1 9}$ & $\mathbf{2 0 2 0}$ & $\mathbf{2 0 2 1}$ & $\mathbf{2 0 2 2}$ & $\mathbf{2 0 2 3}$ & $\mathbf{2 0 2 4}$ & $\mathbf{2 0 2 5}$ & $\mathbf{2 0 2 6}$ & $\mathbf{2 0 2 7}$ \\
\hline Mori Atas & 12.044 & 12.271 & 12.503 & 12.740 & 12.980 & 13.226 & 13.476 & 13.730 & 13.990 & 14.254 \\
\hline Lembo & 15.179 & 15.483 & 15.793 & 16.109 & 16.431 & 16.759 & 17.095 & 17.436 & 17.785 & 18.141 \\
\hline Lembo Raya & 8.250 & 8.338 & 8.426 & 8.515 & 8.606 & 8.697 & 8.789 & 8.882 & 8.976 & 9.071 \\
\hline $\begin{array}{l}\text { Petasia } \\
\text { Timur }\end{array}$ & 15.882 & 16.367 & 16.866 & 17.380 & 17.910 & 18.457 & 19.020 & 19.600 & 20.197 & 20.813 \\
\hline Petasia & 19.263 & 19.937 & 20.635 & 21.357 & 22.104 & 22.878 & 23.679 & 24.508 & 25.365 & 26.253 \\
\hline Petasia Barat & 8.473 & 8.674 & 8.879 & 9.090 & 9.305 & 9.526 & 9.751 & 9.982 & 10.219 & 10.461 \\
\hline Mori Atas & 7.617 & 7.726 & 7.837 & 7.949 & 8.062 & 8.178 & 8.295 & 8.413 & 8.534 & 8.656 \\
\hline Soyo Jaya & 10.515 & 10.928 & 11.356 & 11.801 & 12.264 & 12.744 & 13.244 & 13.763 & 14.303 & 14.863 \\
\hline $\begin{array}{l}\text { Bungku } \\
\text { Utara }\end{array}$ & 16.680 & 16.953 & 17.232 & 17.514 & 17.801 & 18.093 & 18.390 & 18.692 & 18.998 & 19.310 \\
\hline Mamosalato & 12.311 & 12.605 & 12.907 & 13.215 & 13.531 & 13.854 & 14.185 & 14.524 & 14.871 & 15.227 \\
\hline Total & $\mathbf{2 , 6 0 \%}$ & $\mathbf{1 0 6 . 8 0 0}$ & $\mathbf{1 0 9 . 5 7 7}$ & $\mathbf{1 1 2 . 4 2 6}$ & $\mathbf{1 1 5 . 3 4 9}$ & $\mathbf{1 1 8 . 3 4 8}$ & $\mathbf{1 2 1 . 4 2 5}$ & $\mathbf{1 2 4 . 5 8 3}$ & $\mathbf{1 2 7 . 8 2 2}$ & $\mathbf{1 3 1 . 1 4 5}$ \\
\hline
\end{tabular}

Appendix 2: Number of Population Aged 15 Years According to Highest Education Completed in 2018

\begin{tabular}{|l|c|c|c|}
\hline \multicolumn{1}{|c|}{ Highest Education completed } & \multicolumn{2}{c|}{ Workforce } \\
\cline { 2 - 4 } & Work & unemployment & Total \\
\hline Never / Never attended school & - & - & - \\
\hline No / Not yet finished elementary school & - & - & - \\
\hline Elementary School & 26.974 & 173 & 27.147 \\
\hline Junior High School & 12.269 & 460 & 12.729 \\
\hline Senior High School / Vocational High School & 13.961 & 469 & 14.430 \\
\hline Diploma & 1.745 & - & 1.745 \\
\hline University & 5.883 & - & 5.883 \\
\hline Main Activities & Men & Women & Total \\
\hline Agriculture, Forestry, Hunting, and fisheries & 23.296 & 9.373 & 32.669 \\
\hline Mining and excavation & 746 & - & 746 \\
\hline Processing industry & 1.111 & 447 & 1.558 \\
\hline Electricity, Gas, and Water & - & 648 & 648 \\
\hline Building & 3.558 & - & 3.558 \\
\hline Wholesale, retail and restaurant and hotel trade & 1.107 & 2.701 & 3.808 \\
\hline Force, warehousing and communication & 1.575 & - & 1.575 \\
\hline Finance, insurance, building leasing, land and business services & 957 & - & 957 \\
\hline Community, social and personal services & 3.718 & 2.461 & 6.179 \\
\hline Total & $\mathbf{3 6 . 0 6 8}$ & $\mathbf{1 5 . 6 3 0}$ & $\mathbf{5 1 . 6 9 8}$ \\
\hline
\end{tabular}

Appendix 3: Location Quotient Analysis

\begin{tabular}{|c|c|c|c|c|c|c|c|c|}
\hline \multicolumn{7}{|c|}{ MINING AND DIGGING (in Indonesian Rupiah) } \\
\hline Year & Eij (regency) & $\begin{array}{c}\text { Ej (PDRB } \\
\text { ADHK regency) }\end{array}$ & Ein (Province) & $\begin{array}{c}\text { En (PDRB } \\
\text { Province) }\end{array}$ & Eij/Ej & Ein/En & LQ & Info \\
\hline 2015 & 2.734 .513 & 5.472 .537 & 7.239 .051 & 71.587 .532 & 0,50 & 0,10 & 4,9 & Base \\
\hline 2016 & 1.203 .197 & 5.897 .217 & 9.223 .195 & 82.803 .203 & 0,20 & 0,11 & 1,8 & Base \\
\hline 2017 & 1.476 .337 & 6.098 .661 & 12.458 .703 & 91.070 .555 & 0,24 & 0,14 & 1,8 & Base \\
\hline 2018 & 2.067 .335 & 6.709 .481 & 14.313 .500 & 97.551 .643 & 0,31 & 0,15 & 2,1 & Base \\
\hline
\end{tabular}


Appendix 4: SWOT Analysis of the North Morowali Regency Mining Sector

\begin{tabular}{|c|c|c|}
\hline & Strength & Weakness \\
\hline Internal Factors & $\begin{array}{l}\text { The mining sector is a sector that } \\
\text { has a significant contribution to the } \\
\text { North Morowali Regency Gross } \\
\text { Regional Domestic Product } \\
\text { Supported geographically }\end{array}$ & $\begin{array}{l}\text { Absorption of labor, especially local } \\
\text { labor in the mining sector, is very small } \\
\text { compared to other sectors } \\
\text { The mining sector has not yet optimally } \\
\text { provided a complex development impact } \\
\text { on infrastructure development in the North } \\
\text { Morowali regency }\end{array}$ \\
\hline Opportunity & Strength - Opportunity & Weakness - Opportunity \\
\hline $\begin{array}{l}\text { Morowali district government can re- } \\
\text { arrange contractual agreements with } \\
\text { mining companies, especially in terms } \\
\text { of employment and social infrastructure } \\
\text { development in North Morowali } \\
\text { Regency }\end{array}$ & $\begin{array}{l}\text { Renegotiation of contractual } \\
\text { agreements in terms of local } \\
\text { employment and infrastructure } \\
\text { construction in North Morowali } \\
\text { District involving mining companies }\end{array}$ & $\begin{array}{l}\text { Involving mining companies to be able } \\
\text { to work in synergy with the regional } \\
\text { government of North Morowali Regency } \\
\text { in terms of infrastructure development in } \\
\text { which District in North Morowali Regency } \\
\text { the mining company operates }\end{array}$ \\
\hline Threats & Strength - Threats & Weakness - Threats \\
\hline $\begin{array}{l}\text { The insignificant absorption of local } \\
\text { labor can affect horizontal conflicts in } \\
\text { North Morowali Regency } \\
\text { Regulations regarding the mining } \\
\text { sector are primarily regulated by the } \\
\text { central and provincial governments. }\end{array}$ & $\begin{array}{l}\text { Increased research on mining } \\
\text { potential in North Morowali Regency }\end{array}$ & $\begin{array}{l}\text { Increased bargaining efforts between } \\
\text { the North Morowali district government } \\
\text { and the mining company regarding the } \\
\text { absorption of local labor } \\
\text { Revise mining regulations that provide } \\
\text { development solutions for North Morowali } \\
\text { district }\end{array}$ \\
\hline
\end{tabular}

Appendix 5: SWOT Analysis of the Human Resources Development Sector

\begin{tabular}{|c|c|c|}
\hline & Strength & Weakness \\
\hline Internal Factors & $\begin{array}{l}\text { Population development in North } \\
\text { Morowali Regency is a capital for the } \\
\text { supply of labor } \\
\text { Government support in efforts to } \\
\text { improve the quality of human resources } \\
\text { The existence of community groups in } \\
\text { supporting the development of resource } \\
\text { management }\end{array}$ & $\begin{array}{l}\text { The level of community skills } \\
\text { that are still lacking } \\
\text { There are still residents who } \\
\text { are registered as job seekers } \\
\text { with low levels of education }\end{array}$ \\
\hline Opportunity & Strength - Opportunity & Weakness - Opportunity \\
\hline $\begin{array}{l}\text { The existence of educational institutions that } \\
\text { play a role in improving the quality of human } \\
\text { resources } \\
\text { Development of economic sector potentials } \\
\text { which provide opportunities for employment } \\
\text { There are job seekers with a high education } \\
\text { level }\end{array}$ & $\begin{array}{l}\text { Increasing access to information } \\
\text { and technology to improve human } \\
\text { resources } \\
\text { Improvement of community } \\
\text { organization institutions }\end{array}$ & $\begin{array}{l}\text { Enhancing community skills in } \\
\text { natural resource management } \\
\text { through skills training }\end{array}$ \\
\hline Threats & Strength - Threats & Weakness - Threats \\
\hline $\begin{array}{l}\text { The willingness of individuals/personal to want } \\
\text { to develop forward depends on each individual }\end{array}$ & Development of socialization media & $\begin{array}{l}\text { Development of socialization } \\
\text { media }\end{array}$ \\
\hline
\end{tabular}

